\title{
NURSES AND THE WORKING PROCESS AT A TEACHING HOSPITAL: IMPLEMENTATION OF THE UNIFIED HEALTH SYSTEM ${ }^{1}$
}

\author{
Daiane Siqueira de Luccas², Liliana Müller Larocca ${ }^{3}$,Maria Marta Nolasco Chaves ${ }^{4}$, Elizabeth Bernardino
}

${ }^{1}$ This study is part of the thesis - Nurses' work process at a public teaching hospital: changes after the implementation of the Unified Public Health System, presented to the Programa de Pós-Graduação em Enfermagem, Universidade Federal do Paraná (UFPR), in 2013.

${ }^{2}$ Master's student in the Graduate Program in Nursing of UFPR. Curitiba, Paraná, Brazil. E-mail: daiane_luccas@hotmail.com

${ }^{3}$ Ph.D. in Education. Professor at the Nursing Department and the Graduate Program in Nursing of UFPR. Curitiba, Paraná, Brazil E-mail: larocca_m@terra.com.br

${ }^{4}$ Ph.D. in Nursing. Professor at the Nursing Department and the Graduate Program in Nursing of UFPR. Curitiba, Paraná, Brazil E-mail: mnolasco@terra.com.br

${ }^{5}$ Ph.D. in Nursing. Professor at the Nursing Department and the Graduate Program in Nursing of UFPR. Curitiba, Paraná, Brazil E-mail: elizabeth.bernardino@hotmail.com

\begin{abstract}
Study guided by Norberto Elias's theoretical, methodological background, which objectified to analyze the changes in nurses' work process at a Teaching Hospital since the implementation of the Unified Health System. Data were gathered by means of an interview applied to 12 nurses working in the studied setting since 1990, with further discourse analysis. Eight themes emerged as results (integrality, decentralization, hierarchization, regionalization, work process, health funding and social control), and 35 thematic statements, categorized from concepts of figuration, interdependence and tension balance, which enabled discussions on relational dynamics between society and individuals in order to apply Unified Health System principles, and tension production to carry out the work process. We concluded that Unified Health System implementation-ridden changes reflected on such professionals' work process even indirectly.

DESCRIPTORS: Nursing. Health public policy. Unified Health System.

\section{ENFERMEIROS E O PROCESSO DE TRABALHO DE UM HOSPITAL DE ENSINO: IMPLANTAÇÃO DO SISTEMA ÚNICO DE SAÚDE}

RESUMO: Estudo guiado pelo referencial teórico-metodológico de Norbert Elias cujo objetivo foi analisar as transformações no processo de trabalho dos enfermeiros de um Hospital de Ensino a partir da implantação do Sistema Único de Saúde. Os dados foram obtidos por meio de entrevista aplicada a 12 enfermeiros atuantes no cenário do estudo desde 1990, com posterior análise dos discursos. Como resultados emergiram oito temas (universalidade, integralidade, descentralização, hierarquização, regionalização, processo de trabalho, financiamento da saúde e controle social) e 35 frases temáticas, categorizadas a partir dos conceitos de figuração, interdependência e equilíbrio de tensões, o que permitiu discussões sobre a dinâmica relacional entre sociedade e indivíduos para aplicabilidade dos princípios do Sistema Único de Saúde e produção de tensões na realização do processo de trabalho. Concluímos que as transformações induzidas pela implantação do Sistema Único de Saúde refletiram no processo de trabalho destes profissionais, ainda que indiretamente. DESCRITORES: Enfermagem. Políticas públicas de saúde. Sistema único de saúde.

\section{LOS ENFERMEROS Y EL PROCESO DE TRABAJO DE UN HOSPITAL DE ENSEÑANZA: IMPLANTACIÓN DEL SISTEMA ÚNICO DE SALUD}

RESUMEN: Estudio guiado por el referencial teórico-metodológico de Norbert Elias, cuyo objetivo ha sido analizar las transformaciones en el proceso laboral de los enfermeros de un Hospital de Enseñanza, a partir de la implantación del Sistema único de salud. Los datos fueron obtenidos por medio de uma entrevista realizada con 12 enfermeros actuantes, desde 1990, en el escenario del estudio y por un posterior análisis de los discursos. En cuanto a los resultados, surgieron ocho temas: universalidad, integralidad, descentralización, jerarquización, regionalización, proceso de trabajo, financiación de la salud y control social) y 35 frases temáticas, categorizadas a partir de los conceptos de figuración, interdependencia y equilibrio de tensiones, lo que permitió discusiones sobre la dinámica relacional entre la sociedad y los individuos para la aplicabilidad de los principios del Sistema único de salud y la producción de tensiones en la realización del proceso de trabajo. Concluimos que las transformaciones inducidas por la implantación del Sistema único de salud se reflejaran en el proceso de trabajo de estos profesionales, aunque indirectamente.

DESCRIPTORES: Enfermería. Políticas públicas de salud. Sistema único de salud. 


\section{INTRODUCTION}

The establishment of societies does not involve only a sum of individuals, since individual and collective identities are subjected to context and structural changes taking place in a given society. Therefore, individuals in society develop interdependent functions with structures and standards that provide specificity to some social groups.

In Brazil, the implementation of the Unified Health System (SUS - Sistema Único de Saúde) in 1990 can be understood as one of the model cases for social changes, with direct and remarkable impacts on the training and work of nurses. The sociologist Norbert Elias refers to this kind of change as a civilizing process and brings elements to understand the changes caused on human behavior in society which, in this paper, is represented by the implementation of the Unified Health System in a public teaching hospital in the state of Paraná. ${ }^{1}$

It is widely known that subjects are responsible for social transformations in the space they live, through their working process. Likewise, the environment modifies the subjectivity of individuals and, as such, discovering the network of interdependencies between them is crucial, which could interfere on the nurses' habitus - the way individuals behave in their interdependence net, generated from two phenomena: social control and self-control. ${ }^{2}$

To understand the changes in the nursing working process and highlight the importance of public teaching hospitals to the professional category as a setting of work, training and knowledge production, this study uses the historical excerpt of the Brazilian Health System enactment as legal ground and the theoretical approach proposed by Elias to understand this duty.

This excerpt was selected due to the discussions held 25 years after the SUS implementation. Although some studies emphasize the progress in the Brazilian health sector related to the implementation of the SUS and extinction of the National Institute of the Social Security Medical Care (Inamps - Instituto Nacional de Assistência Médica da Previdência Social), to the expansion of the Family Health Program (PSF - Programa Saúde da Família) and the growth of production and productivity in health care, the broken promises are also highlighted and exemplified by the underfunding of the program and the struggle for universal and fair coverage..$^{3-4}$
The social formation configured in the SUS implementation process brings variable dimensions that are categorized by a given institution, territory, city, nation, among other aspects. All these formations clearly show the networks of interdependence between different social players, which generate a historical production in societies.

In face of the aforementioned, the aim of this study was to analyze the changes in the working process of nurses in a public teaching hospital since the implementation of the Unified Health System.

\section{METHODOLOGY}

An exploratory qualitative study was developed, with a theoretical-methodological approach based on the studies by sociologist Norbert Elias, notably on the construction of individual and collective identities and the idea of society as a figuration of interdependent functions (configuration, interdependence and balance of tensions) which is intertwined with the history of the individuals that make it up. ${ }^{1}$

The concept of configuration stands for the relational dynamics between society and individuals, or even between society and nurses, unveiling the routines, rules, laws and implicitly the invisible work links. In this study, the teaching hospital was the dimension that permeates the social formation of subjects. ${ }^{1}$

The configuration exposed by the sociologist assumes the existence of a network, based on the concept of interdependence, which represents the connection of individuals through a phenomenon of mutual dependence. ${ }^{1}$ Here, the relationships of dependence established between professional nurses, the team of workers in the institution and the users of the Unified Health System are considered.

Twelve nurses (11 women and 1 man) participated in this study and met the following inclusion criterion: being active nurses in 1990 at the teaching hospital located in the municipality of Curitiba, regardless their sex and age.

The nurses formalized their voluntary participation by signing a Free and Informed Consent Form (FICF), and their anonymity was ensured by replacing their names with the acronym NUR followed by Arabic numerals in ascending order, following the order of interviews, ranging from NUR01 to NUR12.

Data were collected by means of semistructured interviews carried out from May to June 2013. The interview comprised two questions 
and a script designed according to the analytical categories established by the theoretical approach of Norbert Elias - configuration, interdependence and balance of tensions.

The three-stage analysis of discourse was employed, as it enables a broader understanding of the context exposed by the social actors, and because it includes social, historical, and ideological aspects. ${ }^{5}$

Each ideology referred to corresponded to a discursive formation with a set of topics and figures. The figures were related to an element of the natural world, perceived in the discourse as a simulation of this world - for example, concrete nouns or verbs that indicate physical activities. The topic, in turn, is part of the discursive semantic and cannot be considered as something belonging to the natural world, as it is part of the categories that rule reality, like solidarity, honor and exploration. ${ }^{6}$

The discourses were decomposed by a thorough reading of the text to identify topics and figures, which allowed unveiling the meaning of the statements, as shown in Figure $1 .^{6}$

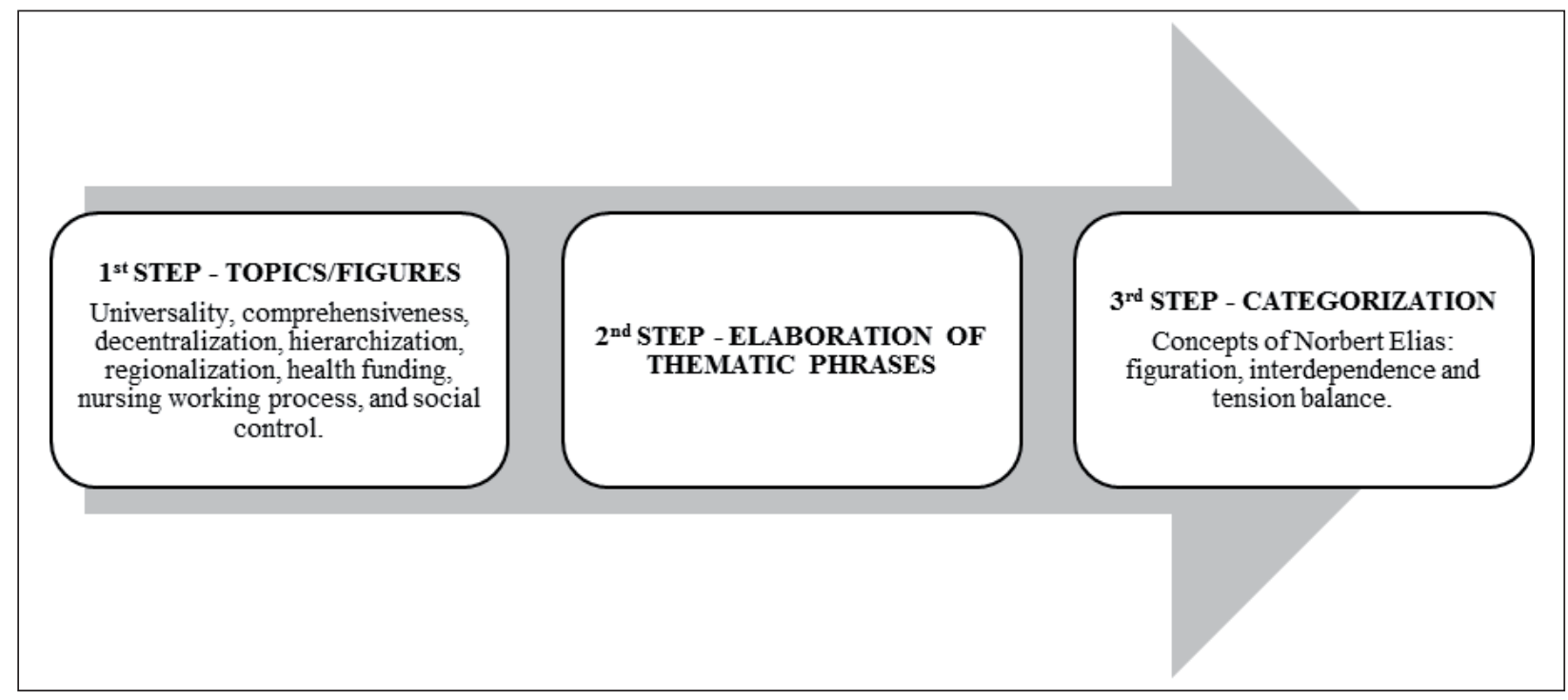

Figure 1 - Stages of the discourse analysis used in the study. Curitiba, 2013

In the second step of analysis, the topics and figures were concatenated/coordinated to identify their coherences and divergences in the participants' discourses. The result was the elaboration of thematic phrases that defined the topics and sub-topics of the discourse as a whole. In the third step, the thematic phrases were grouped to categorize the empirical material. Depending on the topics identified, the following categories have emerged from this study: configuration, interdependence and balance of tensions. ${ }^{6}$

The research proposal for this study was approved by the Human Research Ethics Committee of the HC/UFPR, according to the protocol $249407 / 2013$.

\section{RESULTS AND DISCUSSION}

The existing tensions in the everyday of individuals lead to changes in the balance of power (balance of tensions) and result in structural changes in society. ${ }^{1}$ The changes caused by the SUS implementation on the working process of nurses are originated by tensions and can be observed in this study.

The discourse analysis brought about eight topics: universality, comprehensiveness, decentralization, hierarchization, regionalization, working process, health funding and social control. Thirty-five phrases were built in the step of Elaboration of Thematic Phrases. In the last step, Categorization, the thematic phrases were classified following the three concepts of Elias (configuration, interdependence and balance of tensions). In this study, we will present only 14 thematic phrases, in addition to their links with the concepts of the theoretical approach found in the discussions of the topics elected.

\section{Topic: comprehensiveness}

The high number of phrases in this topic, specifically regarding the concept of configuration, reinforces the existence of relational dynamics be- 
tween society and individuals, which refers to the Brazilian health system that proposes the existence of interconnections among care complexity degrees through the principle of comprehensiveness.

This study considered the presentation of comprehensiveness proposed by Law 8080/90 which, in Article 7, defines it as a coordinated and continuous set of actions and preventive and healing services required to each case, at all levels of the system complexity. ${ }^{7}$

The discourses brought about this principle when the subjects referred to the changes after the SUS implementation.

In the past, patients sought the HC for simple diagnosis, but today the most critically ill patients come here (NUR01, NUR02, NUR08, NUR12).

The noticeable change refers to family care, the humanization program, children care and women's health (NUR10, NUR05).

Health care systems should be connected by the users' health needs. This form of organizing services is called Health Care Network, and is defined as an integration of health care units linked by a unique mission that culminates in the delivery of continuous and comprehensive care, with communication between the different levels of service. ${ }^{8}$

Primary Health Care (PHC) is referred to as the insertion of users in this network, and the strategies mentioned by the nurses are part of the PHC and evidence its impact on high-complexity care institutions.

Up to these days, users don't have a clear understanding about the role of the 'Network', as they believe that higher complexity care [hospital] brings better results than the health unit (NUR05).

The building of Health Care Networks is consistently questioned due to its hierarchical organization anchored in primary care, followed by medium and high complexity care. This definition allows understanding the wrong view that Basic Health Care is a low-complexity activity. This biased view makes the population, politicians, managers and health professionals overestimate the secondary and tertiary health care levels. ${ }^{9}$

Health care networks organized as polyarchy should replace this pyramidal model, mainly considering the epidemiological condition of chronic diseases hegemony. Thus, the technological densities rather than the complexity degrees will be valuated, in a way to break vertical relationships and to implement horizontal polycentric networks. ${ }^{9}$
However, despite the difficulty in organizing the Primary Care Networks, there are concrete causes that could have a direct impact on the PHC non-effectiveness and that are implicit in the nurses' discourse. For example, poor physical structure of services, working process and management, training of professionals and shortage of resources to diagnosis support and referral to specialized care. ${ }^{10}$

The failures found in the principle of comprehensiveness implementation bring about tensions in society and have been mentioned in the discourses of the participants.

The counter-referral system still shows failures (NUR02).

This statement corroborates the study carried out in the state of Paraíba in 2012 and in first half of 2013. The study aimed at describing the characteristics of the organization, of articulation and care, about the referral and counter-referral system, and gathered data from the evaluation of professionals in 624 health units. The conclusion was that in Paraíba the referral and counter-referral system is weak, what is clearly shown in the study through the lack of knowledge among professionals about the workflow, vagueness regarding flows, or fragmented referral and counter-referral system in that state. ${ }^{11}$

The inefficacy of the referral and counterreferral system entails several problems. The reflex of this weakness is exemplified by the long time users have to wait to access some services, thus impairing the continuity of treatment. ${ }^{12}$

\section{Topic: funding}

Historically, teaching hospitals have gone through several changes in an attempt to overcome financial and managerial crises, aiming at improving the quality of health care services. The hospital where we carried out this study has also participated in these changes, which were mentioned by the study participants.

The changes that directly interfere with the relational dynamics between society and individuals, considered here as the voice of society through the normative rules established regarding the nurses of the teaching hospital, have been classified under the concept of configuration. The five subjects that have incorporated this topic in their discourses show that invisible labor links are relevant with positive or negative interference on their everyday lives. 
The participants referred to several events of changes: in the past, there were beds for non-contributors, FUNRURAL and INPS (NUR02, NUR12).

The budget to fund procedures that used to be transferred by the Ministry of Education is now transferred by the Ministry of Health (NUR01, NUR02).

The changes referred to by nurses in their discourses came about in the 1980s, and teaching hospitals started being ruled by the Hospitalization Authorization (AIH - Autorização de Internação Hospitalar).$^{13}$

The transition away from the former funding models to the new approaches in the SUS implementation was a must. Early in the 1990s, eleven state hospitals were closed and others drastically reduced the services provided because of the impossibility of funding health with the amounts paid through the agreements with the Social Security. ${ }^{13}$

After the management agreement was signed with the Municipal Health Secretariat in 2004, the financial resources spent in the hospital object of this study became fixed and were provided by the Ministry of Health. ${ }^{13}$

Despite the many changes that followed the Sanitary Reform until the SUS implementation, participants pointed out difficulties regarding health funding in Brazil. These deficits generate tensions in the society's power balance.

The SUS funding does not cope with the hospital expenses and the referral price table is outdated (NUR05).

After the SUS implementation, a tripartite organization of federalist funding in health was promoted. In that organization, the federal government, states and municipalities would be co-responsible for funding the new health system, supported by the Social Security Budget (OSS - Orçamento da Seguridade Social). Although being innovative, this budgetary option reduced resources because of the irregular financial contributions and the fragmentation of health resources. Therefore, the Provisional Contribution on Transactions or Remittance of Values and Credits and Right of Financial Nature (CPMF) tax and the Constitutional Amendment \# 29 (EC 29/2000) emerged as a temporary solution. ${ }^{14}$

The enactment of that Amendment was considered to be a huge progress of the Brazilian health system funding, as it ensured minimum resources to the Brazilian health. However, there were conflicts that posed a barrier to compliance. For example, there were no definitions about which expenses should be considered as health actions and services. There are also conflicts regarding the calculations to use the Federal Government resources. ${ }^{15-16}$

The great problems related to health funding remain up to these days. In 2012, the percentage of the federal government expenditures with health actions and services virtually remained the same as in 1995 , when it was only $1.75 \%$ of the gross domestic product. ${ }^{15}$ These data are even more concerning when we observe the total expenses with health in Brazil, as $47 \%$ correspond to public expenditure. This shows the difficulty faced by the SUS public managers, as the system must provide services to $75 \%$ of the population, who have no private health insurance, and this care is provided with less than half of the resources devoted to health in Brazil. ${ }^{17-18}$

The SUS underfunding is not a current problem: the situation was historically generated by the policies of macroeconomic adjustment, which allot half of the public expenditure to pay expenses with interest, charges and amortization of the Brazilian debt. In addition to that there is the political interest game, lack of governance and irregularities of the political system that reflect in the poor health care provided to citizens, and notably the lack of funding, as disclosed in the discourses of the study participants. ${ }^{14}$

\section{Topic: working process}

This study found some contradictions in the participating nurses' experiences regarding the Brazilian public policies, notably about the SUS, its guidelines, principles, organization and intentionality.

The phrases related to the nurses' working process could be categorized into two concepts of Norbert Elias: interdependence and balance of tensions. Regarding the first concept, some statements refer to mutual dependence, i.e., the nurses' work and the public health policies. The second concept, in turn, evidences the tensions of carrying out the nursing work related to the downs caused by the SUS implementation.

The SUS is correlated with the free health care (NUR03).

There was no difference in the Brazilian health system after the SUS implementation (NUR03, NUR06, NUR07, NUR10, NUR11).

These statements can be understood when we seek for indications of the nurses' participa- 
tion in the Sanitary Reform. Since 1986, there are evidences that this class was not numerically expressive in the period - the higher-education professionals accounted for $30 \%$ of the total health workers and, of these, $17 \%$ were physicians and only $2 \%$ were nurses. ${ }^{19}$ The percentage of nurses in that period did not exceed $8.5 \%$ of the total work power in nursing, with only 25,863 professionals. According to the Federal Nursing Council, in 2010, there were 287,119 nurses. ${ }^{20}$

The lack of engagement with health policyrelated issues in Brazil may have contributed to the perception of the SUS nurses that it is a system that comprises only free health care. Law 8080/90 describes the complementarity with the services provided by the private initiative when resources are not enough to ensure the care coverage, corroborating with the participation of private institutions in the SUS.?

Another fact to be analyzed concerns the academic training of nurses. The historical path of undergraduate courses in this area is marked by countless changes related to the social, political and economical situation in the period.

Today, education in nursing is very close to the needs of health and comprehensive care. The major focus on hospital care was redirected after the insertion of collective health practices in the education process. The intention of adjusting the training process to the new health policies based on the Sanitary Reform and the SUS principles and guidelines was evidenced in a survey carried out in Paraná with political-pedagogical projects of nine nursing undergraduate schools. ${ }^{21}$

Most of the working process-related thematic phrases were categorized based on the concepts interdependence and balance of tensions by Norbert Elias. Some participants do not recognize the changes in their working process induced by the SUS implementation, like in the following statement: There was no difference in nursing care throughout these years (NUR01).

A study developed in 1995 at the Clinics Hospital of Rio Preto, state of São Paulo, corroborated the idea of non-recognition of changes in the nursing working process. However, of the 31 nurses interviewed only 17 nurses $(54.84 \%)$ deny changes in their daily actions after the institution adhered to the SUS. The 14 subjects that referred to changes said the work, by that time, was closer to the patient. During the study, care became demanding, and a stronger focus of this professional category on critically ill patients was needed. ${ }^{22}$

\section{Topic: universality}

The relational dynamics, or the configuration, existing in the Brazilian health system is evidenced in the statements for the topic of universality. The representation of thematic phrases in this category allows observing the correlation between comprehensiveness and universality, which will only be fully provided to the population at large when it is in line with the SUS funding.

The participants' statements reflect that dependence.

The number of hospital beds - just like human resources - was reduced due to the adjustments to the new laws (NUR01, NUR03, NUR05, NUR07, NUR10, NUR12).

Data show that access to health services in Brazil has improved. Prior to the implementation of SUS, $8 \%$ of the population stated to have used the health service in the last 30 days. In 2008, in turn, that index increased $174 \%: 14.2 \%$ of the population had used health services in the last 15 days. ${ }^{3}$

An analysis about funding with a direct impact on universality showed several hospitalizations funded by the public sector. In 1982, the social security system financed 13.1 million hospitalizations/year, whereas in 2009 the SUS funded 11.1 million hospitalizations/year. The reduction on access to hospital care can be justified by the restriction of hospital expenditures by state (according to the population size) that limited the payment of hospitalizations by the Ministry of Health, and by the reduction in potentially avoidable hospitalizations after the creation of some services, such as the Family Health Strategy. ${ }^{3}$

\section{Topic: social control}

In this study, phrases in the category of interdependence were confirmed when participants reinforced the links between users to implement social control. Another category emerges when nurses refer to the existing tensions like the difficulty in putting into practice that principle due to the inexistence of an active local health council in the scenario studied.

Implemented through Law 8142/90 and further amended by Resolution 333/03, the population's social control on the management 
of public health policies takes place through the health council participation. It is currently defined as a collegiate, deliberative and permanent body of the SUS which, in principle, is part of the basic structure of the Ministry of Health, and of the Health Secretariats of states, the Federal District and municipalities. ${ }^{23}$

The objective of the health councils is to work on the formulation and proposition of strategies and on the monitoring of the health policies enforcement, including in its economic and financial aspects. ${ }^{23}$

Thus, according to the nurses interviewed the debates brought knowledge and benefits to SUS users, enabling stronger participation and the consequent demand for their rights.

Users exercise social control when they challenge the investment in the field of health and know their rights (NUR04, NUR05).

However, despite the democratization process permeated by social participation, there is still a long path towards legitimacy, collectivity of decisions and the strengthening of decisionmaking spaces. ${ }^{24}$

The SUS principle of social control is not put into practice, as there is no active local health council (NUR06).

A study performed in Minas Gerais to assess the effective participation of citizens in the Health Municipal Council found that participatory management has not yet been consolidated in the SUS. The incompliance with the parity principles and the political influence as criterion to select the Council members hinder the important process of managing health public policies in Brazil. ${ }^{25}$

\section{Topics: decentralization and regionalization}

Both topics - decentralization and regionalization - are approached together since their concepts are complementary to one another.

The phrases for the topic approached remain in the category of configuration because they represent the dynamics between subjects in the health system. Some current examples are the intergovernmental relationships.

Since the SUS implementation, the state reduced its responsibility in the field of health. On the other hand, the municipality work has been strengthened (NUR06, NUR02).

The idea of decentralization with one single leadership in each governmental level comes about in an attempt to change concepts related to health management, with emphasis on municipalization of care. Management at municipal level would be explained by the continental dimensions of Brazil, where quality care would demand essential services in all corners of the country. ${ }^{26-27}$

The 1988 National Constitution was a hallmark in the process, as it defined the role to be played by the federal government, states and municipalities in the health system, focusing on decentralization. It would provide for the formulation and implementation of health policy, financial resources and health services and actions in the states and municipalities. ${ }^{26}$

The enactment of the 1988 Constitution granted autonomy to municipalities, converting them into federal entities. The model brought some consequences that were not necessarily beneficial: more competitiveness between state and municipalities for increasingly scarce resources and the historical difficulties of the model centered in healing and high-cost practice, and weak focus on health promotion. ${ }^{26}$

\section{FINAL CONSIDERATIONS}

In the working process developed by nurses in the setting under study, the tensions and relations - analyzed in the light of implementation, in the 1990s, of the Brazilian Sanitary Reform assumptions - led us to conclude that the Unified Health System principles are part of the routine of the nurses interviewed and permeate the relationships established by professionals, regardless if nurse-nurse, nurse-user or nurse-health system.

The concept of configuration was the most frequently used to classify the phrases. This corroborates the assertion that relationships established between nurses and the health system are frequently used in their routine. The impositions of the system, the facilities implemented and the resulting difficulties are often quoted in the discourses, unveiling the relational dynamics between them.

Likewise, there are frequent references to the tensions generated. Since these are perceived as barriers to the achievement of the nurses' working object, regardless if care, management, education or research, tensions lead to changes in the society power balance and, as such, are of great relevance.

These subjects have not identified the SUS implementation as a factor of change to the nurses' 
working process. It is argued that the short participation of this professional class in the Sanitary Reform and, still today, in the political decisionmaking spaces, added to the academic training of these professionals, cause a deficit of in-depth knowledge about the health public policies in Brazil and result in impact on the health working process.

However, nurses recognize that Law $8080 / 90$, through its principles and guidelines, has changed the setting studied, notably regarding the topics of comprehensiveness and universality and the uniqueness of health actions funding. Hence, we believe the changes induced by the SUS implementation have influenced the working processes of these professionals, even if indirectly perceived.

\section{REFERENCES}

1. Elias N. On the process of civilisation: revised edition: collected works of Norbert Elias. Dublin (IE): University College Dublin Press; 2012.

2. Veiga CG. Cuestiones teóricas y conceptuales para la investigación de la psicogénesis y sociogénesis de los procesos escolarizadores. Univ Humaníst. 2011 Ene-Jun; 71: 85-100.

3. Paim J, Travassos C, Almeida C, Bahia L, Macinko J. The Brazilian health system: history, advances, and challenges. Lancet. 2011; 377(9779):1778-97.

4. Macinko J, Oliveira VB, Turci MA, Guanais FC, Bonolo PF, Lima-Costa MF. The influence of primary care and hospital supply on ambulatory care-sensitive hospitalizations among adults in Brazil, 1999-2007. Am J Public Health. 2011 Oct; 101(10):1963-70.

5. Minayo MCS. O desafio do conhecimento: pesquisa qualitativa em saúde. $12^{\mathrm{a}}$ edição. São Paulo (SP): Hucite; 2010.

6. Fiorin JL, Savioli FP. Para entender o texto: leitura e redação. $17^{a}$ edição. São Paulo (SP): Ática, 2007.

7. Brasil. Lei $n^{\circ}$ 8.080, de 19 de setembro de 1990 . Dispõe sobre as condições para a promoção, proteção e recuperação da saúde, a organização e o funcionamento dos serviços correspondentes e dá outras providências. Diário Oficial [da] República Federativa do Brasil, 20 Set. 1990.

8. Mendes EV. As redes de atenção à saúde. Ciênc Saúde Coletiva. 2010 Aug; 15(5):2297-305.

9. Mendes EV. As redes de atenção à saúde. Organização Pan-Americana da Saúde. Brasília (DF): OPAS; 2011.

10. Spedo SM, Pinto NRS, Tanaka OY. O difícil acesso a serviços de média complexidade do SUS: o caso da cidade de São Paulo, Brasil. Physis. 2010; 20(3):953-72.

11. Protasio APL, Silva PB, Lima EC, Gomes LB, Machado LS, Valença AMG. Avaliação do sistema de referência e contrarreferência do estado da
Paraíba segundo os profissionais da Atenção Básica no contexto do $1^{\circ}$ ciclo de Avaliação Externa do PMAQ-AB. Saúde Debate. 2014 Out; 38(esp):209-20.

12. Brito-Silva K, Bezerra AFB, Tanaka OY. Direito à saúde e integralidade: uma discussão sobre os desafios e caminhos para sua efetivação. Interface. 2012 Abr; 16(40):249-60.

13. Coser C, Machado-da-Silva CL. Práticas de Assistência no HC-UFPR: a Dinâmica do Processo no Período 1961-2008. In: Anais do Encontro da ANPAD, XXXIV, 2010, p.1-17, Rio de Janeiro, Brasil. Rio de Janeiro (RJ). 2010 [acesso 2013 Out 01]. Disponível em: http://www.anpad.org.br/ diversos/trabalhos/EnANPAD/enanpad_2010/ EOR/2010_EOR2489.pdf

14. Silva C.L da, Rotta CV. O dilema da universalidade e financiamento público do Sistema Único de Saúde no Brasil. Textos \& Contextos. 2012 Ago-Dez; 11(2):333-345.

15. Mendes A. A longa batalha pelo financiamento do SUS. Saúde Soc. 2013; 22(4):987-93.

16. Esteves RJ. The quest for equity in Latin America: a comparative analysis of the health care reforms in Brazil and Colombia. Int J Equity Health. 2012 Feb 2;11:6.

17. Mendes JDV, Bittar OJNV. Perspectivas e desafios da gestão pública no SUS. Rev Fac Cienc Med Sorocaba [online]. 2014 [acesso 2015 abr 27]; 16(1):359. Disponível em http://pesquisa.bvs.br/brasil/ resource/pt/ses-27426.

18. Montekio VB, Medina G, Aquino R. Sistema de salud de Brasil. Salud Pública Méx. 2011 Jan; 53(Suppl 2):120-31.

19. Almeida MCP. A formação do enfermeiro frente à reforma sanitária. Cad Saúde Pública. 1986 Out-Dez; 2(4):505-10.

20. Barreto IS, Krempel MC, Humerez DC. O Cofen e a Enfermagem na América Latina. Enferm Foco 2011; 2(4):251-4.

21. Silva RPG, Rodrigues RM. Sistema Único de Saúde e a graduação em enfermagem no Paraná. Rev Bras Enferm. 2010; 63(1):66-72.

22. Melo MRAC, Fávero N, Évora YDM, Nakao JRS. Modificações no atendimento de enfermagem hospitalar decorrentes do Sistema Único de Saúde (SUS). Rev Latino-Am Enfermagem. 1998 Out; 6(4):5-14.

23. Brasil. Resolução n. 333, de 04 de novembro de 2003: aprova as diretrizes para criação, reformulação, estruturação e funcionamento dos Conselhos de Saúde. Diário Oficial [da] República Federativa do Brasil, 4 Dez. 2003.

24. Soratto J, Witt RR. Participação e controle social: percepção dos trabalhadores da saúde da família. Texto Contexto Enferm [online]. 2013 [acesso 2015 Apr 21]; 22(1):89-96. Disponível em: http://www. 
scielo.br/scielo.php?script=sci_arttext\&pid $=$ S010407072013000100011\&lng=en

25. Cotta RMM, Martins PC, Batista RS, Franceschinni SCC, Priore SE, Mendes FF. O controle social em cena: refletindo sobre a participação popular no contexto dos Conselhos de Saúde. Physis. 2011; 21(3):1121-37.
26. Organização Pan-Americana da Saúde. Redes e regionalização em saúde no Brasil e na Itália: lições aprendidas e contribuições para o debate. Brasília (DF); 2011.

27. Fleury S. Brazil's health-care reform: social movements and civil society. Lancet. 2011 May; 377(9779):1724-25. 